\title{
From Export Entry to De-internationalisation through Entrepreneurial Attributes
}

\author{
Esteban Lafuente* \\ Department of Management, Universitat Politècnica de Catalunya (Barcelona Tech) \\ EPSEB, Av. Gregorio Marañón, 44-50, 3era planta. 08028. Barcelona. Spain \\ Email: esteban.lafuente@upc.edu
}

\author{
Cristina Stoian \\ Brunel Business School, Brunel University, Uxbridge, UB8 3PH, UK \\ Email: cristina.stoian@brunel.ac.uk \\ Josep Rialp \\ Department of Business Economics, Universitat Autònoma de Barcelona \\ Edifici B, 08193 Bellaterra (Barcelona) Spain \\ Email: josep.rialp@uab.es
}

Acknowledgements: Esteban Lafuente acknowledges financial support provided by the Spanish Ministry of Education and Science (ECO2010-21393-C04-01).

NOTE: Paper published in the Journal of Small Business and Enterprise Development.

Please quote as:

Lafuente, E., Stoian, C., Rialp, J. (2015). From Export Entry to De-internationalisation

through Entrepreneurial Attributes. Journal of Small Business and Enterprise

Development, 22 (1), 21-37.

DOI: http://dx.doi.org/10.1108/JSBED-09-2012-0101

\footnotetext{
* Corresponding author
} 


\title{
From Export Entry to De-internationalisation through Entrepreneurial Attributes
}

\begin{abstract}
Purpose: This study examines export behaviour from a broad perspective considering the influence of entrepreneurial attributes on export entry, export sustainability and deinternationalisation in Romanian small and medium-sized enterprises (SMEs).
\end{abstract}

Design/methodology/approach: Based on theoretical underpinnings from the Resource-Based View (RBV) of the firm and the Institutional Economics (IE) framework, the proposed hypotheses are tested with a rich survey dataset of 319 Romanian SMEs. The data are analysed by means of a multinomial logit regression.

Findings: The study reveals that exporting is not a single event and that variables commonly used to study export propensity linked to the entrepreneurial attributes have a differential influence over the export decisions. More concretely, export entry is positively impacted by the presence of management studies and an entrepreneurial team while sustainment in the international arena is strongly and positively influenced by decision-makers' prior labour experience. De-internationalisation is explained by the entrepreneurs' fear of business failure. The conclusions of this study point towards a holistic view of export policy-making revealing relevant implications for SMEs' internationalisation.

Originality/value: This study enriches the international business literature by simultaneously examining different export decisions, namely export initiation, sustainability and de-internationalisation, at the SMEs' level in a Central and Eastern European (CEE) emerging market. The paper also highlights the dynamic character of entrepreneurial resources and suggests that at distinct stages in the international development of a SME, different entrepreneurial attributes may play a significant role.

Keywords: Export entry, export sustainability, de-internationalisation, entrepreneurial attributes; SMEs.

Paper type: Research paper 


\section{From Export Entry to De-internationalisation through Entrepreneurial Attributes}

\section{Introduction}

This study analyses export behaviour from a comprehensive perspective by examining the entrepreneurial factors that influence international entry, sustainability and de-internationalisation of small and medium-sized enterprises (SMEs). The justification of this research is based on the growing interest of academics and policy makers in SMEs' international strategy and the potential benefits derived from internationalisation in terms of market competition, employment and technology implementation (European Commission, 2010, 2011; Manolova et al., 2010; Fletcher and Prashantham, 2011; Lamb et al., 2011; Prashantham, 2011). Although SMEs increasingly engage in higher-commitment entry modes (Dimitratos et al., 2010; Prashantham, 2011), exporting remains the most common mechanism chosen by SMEs to enter in international markets (Morgan et al., 2012). Exporting is especially appealing to SMEs as it represents a lower-commitment entry mode and therefore, the economic cost and risk borne by the entrepreneur are lower compared to alternative foreign entry modes.

Internationally active SMEs in the European Union (EU) show significantly higher average returns and employment levels, as well as greater innovation rates compared to their non-internationalised counterparts (European Commission, 2010). It is thus fundamental for Europe to increase the capacity and effective internationalisation of SMEs (European Commission, 2011).

Although previous research demonstrates that exporting is a valid mechanism to improve SMEs' performance, these companies generally have limited resources and capabilities at their disposal and this diminishes their capacity of getting involved in and sustaining export operations (Manolova et al., 2010). To date, most research tends to analyse exporting from a static perspective focusing mainly on export propensity and/or export performance (Leonidou et al., 1998; Manolova et al., 2002; Sousa et al., 2008; Wheeler et al., 2008).

But do these arguments imply that export-based internationalisation is a sustainable strategy for SMEs? Is the decision to export and its continuity linked to the presence of specific factors that condition the different export-based internationalisation choices? Yet, given the complexity and increased dynamism of the international 
business environment entrepreneurs may perceive that their already existing export operations do not represent a viable and profitable strategy anymore. In this scenario incentives to withdraw from foreign operations rise and the exit from international markets can become the desired objective.

For the empirical analysis, we use a rich dataset of Romanian SMEs for the year 2008. While existing evidence suggests that Central and Eastern European (CEE) based small firms started venturing in the international arena (e.g.: Ruzzier et al., 2007; Malo and Norus, 2009; Manolova et al., 2010; Miocevic and Crnjak-Karanovic, 2011), most of the limited existent literature on emerging market companies is centred on the analysis of the international behaviour of large multinationals (Yamakawa et al., 2008). International business and marketing scholars highlighted the internationalisation of small firms from emerging economies as a fruitful research avenue (Manolova et al., 2010; Zou and Ghauri, 2010).

In particular, our data allowed us to distinguish between firms that have exported since 2006 or started exporting in 2008 and SMEs that stopped exporting in 2008. The Romanian context is attractive since this CEE country has undergone a profound restructuring process that led to a radical shift from a centrally planned towards a market-oriented economy. One of the most important challenges faced by Romania relates to the development of competitive SMEs (Smallbone and Rogut, 2005). This is especially evident when looking at the international performance of Romanian SMEs. The statistics made available by the European Commission (2010) indicate that $18 \%$ of Romanian SMEs export, a rate that is below the European average (25\%). This signals that in terms of internationalisation Romanian SMEs are in a weaker position relative to their European counterparts.

Thus, Romania represents a fertile ground for researching the emergent international behaviour showed by local firms with little experience in competitive economic settings (Meyer and Gelbuda, 2006). In addition, few empirical studies focus on the international behaviour of the CEE firms (Smallbone et al., 1998; Ruzzier et al., 2007; Manolova et al., 2010; Miocevic and Crnjak-Karanovic, 2011). The dearth of research specifically addressing Romanian SMEs' international involvement gives further relevance to the analysis proposed here.

This study contributes to the international business and management literatures. Based on the Resource-Based View (RBV) and the Institutional Economics (IE), the paper proposes that exporting should not be regarded as an isolated event and 
recognises the importance of simultaneously analysing SMEs' export involvement and export sustainability.

The reminder of this study is organised as follows. Section 2 is dedicated to the theoretical background of the study. A literature review focused on the entrepreneurial determinants of export behaviour is presented in section 3. Next, section 4 describes the data and the methodological approach adopted. The empirical results are presented in section 5 and discussed in section 6. The final conclusions and implications are displayed in section 7 .

\section{Theoretical underpinnings}

To be successful, businesses ought to have the appropriate resources for international expansion (Dhanaraj and Beamish, 2003; Hitt et al., 2006). Internationalisation scholars have lately started relying on one of the dominant theoretical perspectives in business strategy literature, the Resource-Based View for explaining firm internationalisation (Peng, 2001; Tolstoy and Agndal, 2010; Evers, 2011).

According to the RBV, businesses are conceived as bundles of different resources which they use to gain and maintain a competitive market position. These resources are broadly defined as entrepreneurial, organisational and technological (Penrose, 1959). Resources are heterogeneously distributed across firms and the capacity to create specific combinations conditions the adoption and effectiveness of strategies (Barney, 1991; 2001). Bloodgood et al. (1996) relate the above to international expansion arguing that those firms which present unique bundles and combinations of resources' stocks might have a higher proclivity towards internationalisation. Considering that successful internationalisation of SMEs relies on mitigating liabilities of smallness and foreignness, the RBV gains increased relevance and applicability for studying and understanding these companies' international behaviour (Dhanaraj and Beamish, 2003; Loane and Bell, 2006; Ruzzier et al., 2007).

In particular, SMEs from transitional economies are in many cases less resourceendowed compared to their counterparts in more developed markets (Manolova et al., 2010) and have to undergo higher costs of internationalisation due to institutional void. While in the long run, the fundamental economic and political reforms implemented set the basis of a market-oriented economy, they brought alongside, in the short run, an elevated degree of uncertainty and regulatory vacuum which deterred access to 
resources, such as financial and technological capital and therefore, restricted the growth opportunities of newly created entrepreneurial firms (Kelemen, 1999; Meyer and Peng, 2005; Meyer and Gelbuda, 2006; Mano and Norus, 2009). For example, credit constraints were reported to have been a major impediment for small firms' growth in the CEE countries during the early transition stages (Pissarides, 1999; Cottarelli et al., 2005). As a natural consequence, these firms may rely upon inherent, intangible resources that often are present in SMEs by default.

Drawing on the RBV's insight, firms' decision-makers may represent some of the most valuable, unique and difficult to imitate resources (Castanias and Helfat, 2001; Peng, 2001; Dhanaraj and Beamish, 2003; Evers, 2011). The international business literature acknowledges entrepreneur's capital as a valuable asset that can foster SMEs' international activity, often acting as a substitute for tangible resource scarcity and hence, constituting a potential source of differential advantage for the internationalised small firm (Leonidou et al., 1998; Manolova et al., 2002; Wheeler et al., 2008; Liesch et al., 2011).

The choice of the RBV for articulating the theoretical underpinnings of this study is also motivated by its appropriateness for the analysis of export involvement and sustainability. More concretely, the competitive advantage a firm may enjoy at one time does not necessarily 'last forever', as the business environment and resulting challenges businesses are subject to, are constantly changing (Barney, 1991). Drawing on Bloodgood et al. (1996), SMEs which may benefit from a unique resources' combination that facilitates the attainment of a competitive advantage on international markets (e.g. specific entrepreneurial knowledge or skills), may at a later date find themselves in the situation where this resources' bundle does not represent a competitive advantage anymore. So, it is relevant to consider resources and capabilities from a dynamic perspective, keeping in mind that they may change, substitute each other and be combined in various ways during firm's existence.

Given the above considerations, this paper focuses on certain attributes of the entrepreneur that we consider relevant in the Romanian context in order to explain the international involvement and maintenance of Romanian SMEs.

Considering that this study adopts entrepreneurial specific attributes (resources) that have been recognised as relevant by the international business literature for explaining the export behaviour and contextualises them to the Romanian context the theoretical framework of this research relies not only on the RBV of the firm but also on 
underpinnings from the Institutional Economics. The integration of both approaches provides a theoretical base for understanding how, in emerging markets, environmental factors and resources/capabilities of firms explain internationalisation decisions.

We believe that the context surrounding the firm has a direct effect on how resources as well as capabilities can be developed. In other words: the way in which the resource-based perspective can explain internationalisation decisions depends mostly on the empirical context of the application itself. That is the reason why, from our perspective, the integration of the IE and the RBV provides our research with a robust framework, which takes into account the environmental context, the role of formal and informal institutions in the economic and social development, and the resources and capabilities of firms for understanding the strategic decisions the entrepreneurs may take in their respective SMEs.

Recently, the IE framework that develops a very wide concept of "institutions" (Lafuente et al., 2007), has been utilised for studying different topics related to entrepreneurship (Vaillant and Lafuente, 2007; Stephen et al., 2009). This framework focuses on understanding the role of the evolutionary process and that of institutions in shaping economic behaviour. With its antecedents in Veblen's work, the IE emphasises a broader study of institutions and views markets as a result of the complex interactions of these various institutions (e.g. individuals, firms, states, social norms). The general idea that could be derived from studies adopting the IE as a theoretical framework is that institutions affect the structure of incentives and opportunities perceived by entrepreneurs and consequently, their decisions.

North (1990: 3) points out that "institutions are the rules of the game in a society, or more formally, institutions are the constraints that shape human interaction". Therefore, by establishing a stable structure for human interaction, institutions reduce uncertainty and also, as recognised by different authors (North, 1990, 2005; Lafuente et al., 2011), strongly influence the goals and beliefs of individuals, groups and organisations. Similarly, firms, teams and entrepreneurs, can take advantage from the opportunities and limitations provided through the institutional framework for developing different activities and competitive strategies.

Likewise, North (1990) also distinguishes between formal and informal institutions and considers that formal institutions are subordinate to informal ones. For understanding this subordination it is important to note that formal institutions are referred to regulations, normatives, contracts, etc.; while informal institutions are 
referred to attitudes, values or codes of conduct among others. In this sense, "informal institutions come from socially transmitted information and are a part of the heritage that we call culture" (North, 1990: 37). Thus, formal institutions structure the interactions of a society in line with the cultural guidelines that constitute its informal institutions. As a consequence of the previous considerations, we could say that the IE allows us to consider the environment conditions that fix the rules of the game where firms operate.

\section{Literature review and hypotheses development}

Based on previous specific literature which has identified entrepreneurial/managerial attributes as truly relevant for explaining firms' internationalisation behaviour (Leonidou et al., 1998; Manolova et al., 2002; Loane et al., 2007; Sousa et al., 2008; Wheeler et al., 2008) we selected the entrepreneurial attributes that we expect to influence the export behaviour of small Romanian firms keeping in mind the idiosyncrasy of its transitional context. For this reason, we focused on the decision-makers' attributes which required and consequently, experienced a shift (when compared to the communist regime business mechanisms) for allowing the newly created entrepreneurial firms to successfully operate in a transitional economy and beyond (Ellman, 1994; Kelemen, 1999; Uhlenbruck et al., 2003; Brown et al., 2005; Lafuente and Rabetino, 2011) such as: managerial studies, labour experience, the presence of an entrepreneurial team and finally perceived fear of business failure.

The first analysed characteristic of the entrepreneur relates to education on business management. Formal education represents an investment in human capital and it enhances entrepreneurs' knowledge, problem-solving ability, discipline and the capacity to introduce practices within the firm that may enhance business success. Previous research shows that more educated entrepreneurs are associated with internationalisation (Cavusgil and Naor, 1987; Ibeh, 2004). This factor is especially relevant in the case of Romania as under the centrally planned system education was biased towards hard sciences and engineering, in part neglecting social sciences, law and market-oriented studies (Uhlenbruck et al., 2003; Brown et al., 2005; Lafuente and Rabetino, 2011). Moreover, knowledge of conducting businesses in foreign markets was very limited, as international trade was carried out via state-owned intermediaries (Meyer and Gelbuda, 2006). Consequently, one of the challenges faced by Romanian SMEs particularly prevalent at the beginning of the '90s related to developing 
knowledge, skills and know-how of running businesses in the emergent market economy. In this sense, management studies intensively promoted and pursued by Romanian universities during the transition period represent a way to alleviate potential resources' shortages and enhance international business activity. Therefore, we hypothesise that:

H1: The completion of managerial studies by the entrepreneur a) increases the probability of export entry and b) increases the probability of export sustainability.

The international business literature associates the professional experience of the decision-maker with exporting (Leonidou et al., 1998; Wheeler et al., 2008; Evers, 2011). Work experience provides entrepreneurs with specific knowledge and managerial capabilities that may help them develop more successful international strategies. Bell et al. (2004) observe that decision-makers' knowledge and understanding of the industry leads to a high level of international commitment. In Romania, the transition from a centrally planned to a market-oriented economy represented a fundamental shift of the role played by firms in the society and hence, their aims and responsibilities. Before 1990 international trade was controlled by branch ministries (Kelemen, 1999) and this centralisation limited managers' capacity to know their international customers and discouraged initiatives such as searching for foreign customers and suppliers (Meyer and Gelbuda, 2006). During the past two decades, progressive reforms helped consolidating the new governance system and represented the threshold beyond which the accumulation of market-oriented work experience started. Furthermore, the greater exposure to international competitors in the domestic market enhanced business experience and the international involvement of Romanian SMEs (Meyer and Gelbuda, 2006). Considering the above, we expect labour experience gained during the transition stage to act as stimulus for international operation. Thus, we propose:

H2: Labour experience a) increases the probability of export entry and b) increases the probability of export sustainability. 
Increased attention has been paid to the role played by entrepreneurial teams in the international business literature for attaining business success in the international arena (Reuber and Fisher, 2002; Nielsen, 2010). Empirical findings by Loane et al. (2007) suggest that firms formed and/or managed by teams attain superior results in terms of internationalisation speed, market spread and export intensity. These authors further explain that collectively, teams generally comprise more knowledge while their combined contact network is likely to be superior to that of a single decision-maker. Previous analyses of the CEE economies highlight that entrepreneurial teams equal to the sum of the resources and abilities of their members (Uhlenbruck et al., 2003). The knowledge embedded in the entrepreneurial team may improve decision-making processes, firm credibility and the identification of business opportunities. Furthermore, according to the above study, the heterogeneity provided by top management teams enhances management effectiveness and this is expected to provide a stronger capacity to develop, integrate and apply new knowledge and resources. From these arguments we propose the following hypothesis:

H3: The presence of an entrepreneurial team a) increases the probability of export entry and b) increases the probability of export sustainability.

Explanations of firm internationalisation as well as international entrepreneurship literature have generally relied on risk and uncertainty perceptions as a relevant determinant of international involvement (Liesch et al., 2011). Risk tolerance plays a significant role for export propensity (Leonidou et al., 1998) as well as for further international enhancement, as a variety of risks can hinder SMEs' internationalisation (Ruzzier et al., 2007). The centrally planned system rewarded plan attainment and suppressed risk taking initiatives breeding instead habits of obedience and 'playing it safe' behaviour (Ellman, 1994). It is therefore expected that some reminiscence of the former regime would persist during the transition towards a market-driven economy. Moreover, governments during transition do not provide the necessary incentives for entrepreneurs to take high risks of failure. Public administrations are directly or indirectly accountable for: not assuring a competitive environment and coherent strategy to support entrepreneurial activities; contradictory laws and regulations; administrative discretion; the repressive state of taxation; and high short-term interest rates (Luthans et $a l ., 2000)$. Drawing from the above arguments, the Romanian context represents an 
interesting economic setting for studying the influence of risk aversion on SMEs' international behaviour, due to their socialist heritage and current transitional identity. Thus, we hypothesise:

H4: A higher level of perceived risk a) decreases the probability of foreign market entry and b) decreases the probability of export sustainability.

\section{Data and method}

\subsection{Data}

The dataset used in this study is derived from the Romanian Centre for Entrepreneurship and Business Research (CEBR). The CEBR is an organisation which promotes and develops research in the fields of entrepreneurship and international business in Romania. The data were collected in February-April 2009 by means of a survey, designed to provide information about selected performance and organisational characteristics of Romanian SMEs, as well as of their corresponding entrepreneurs. Data collection relied on a structured questionnaire where entrepreneurs were asked to answer essentially closed questions. The questionnaire was subject to a pre-test in order to correct potentially misleading or confusing questions. Previous empirical evidence using the CEBR datasets can be found in Lafuente and Rabetino (2011).

The survey was directed to a population of 852 Romanian SMEs in manufacturing, retail and service sectors. A total number of 402 observations were obtained. Given the purpose of the study and in the interest of following a rigorous methodology, we carried out a sampling procedure aiming to ensure the robustness of our results. First, we included in our final sample only those observations for which a complete dataset of the dependent and independent variables could be constructed. We are also aware that self-employment can be used by businesses as a contractual basis for labour relations. Therefore, in a second step, we considered in the final sample only those individuals who created a company with at least one employee in the first year of operations. After this sampling process, our final sample comprises information for 319 Romanian SMEs, of at most 100 employees, representing an effective response rate of $37.44 \%$ (Table 1). 
Following the NUTS criteria established by EUROSTAT (1999), we observe that our sample demonstrates an appropriate geographical spread throughout Romania, where nearly $18 \%$ of firms are located in Bucharest and a significant representation of SMEs can also be found in the South-East (17.24\%) and the South-West regions $(16.61 \%)$.

\subsection{Variable definition}

The dependent variable used to test our hypotheses is export behaviour and it is measured through a variable that considers the three mutually exclusive actions related to exporting. Under the concept of 'movement in-and-out of exporting' we capture the effects that the selected independent variables have upon the three possible strategic choices that firms can take in terms of export activity. Facing these scenarios, we constructed the dependent variable by recording the different types of export behaviour as 'zero-nonzero' values where a zero indicates that the firm is not involved in export activities and a positive value otherwise. The final positive value depends on the type of export behaviour. We first identified those firms that started exporting in 2008 and a value of one is assigned to these cases. Next, we identified from the remaining observations those with continuous exports. Here, a SME is deemed a continuous exporter if the business exports since 2006 or earlier and in this case the variable takes the value of two. Finally, we searched in the remaining data those firms that stopped exporting in 2008 and a value of three is assigned to them. The population of exporting SMEs in our sample includes 45 regular exporters (average export intensity of 56.6\%) and ten firms that started exporting in 2008 (average initial export intensity of 43.50\%). Also, five firms in our sample de-internationalised in 2008 (average export intensity of $13.60 \%$ in 2007).

We use a set of independent variables commonly found in models centred on export behaviour (Leonidou et al., 1998; Manolova et al., 2002; Loane et al., 2007; Sousa et al., 2008; Wheeler et al., 2008) related to the entrepreneur's human capital; the descriptive statistics are presented in Table 2. Here we considered a dichotomous variable related to the completion of business management studies, labour experience expressed in years and a count variable that represents the number of founding members, where values greater than one indicate the presence of an entrepreneurial team. In the case of the risk perception, we created a dichotomous variable taking the value of one if the entrepreneur asserts that he/she perceives fear of business failure and 
zero otherwise. At this point, an important consideration is taken into account. We are aware that individual perceptions not only change over time, but also are affected by cognitive bias that results from increased knowledge, experience or due to the exposure to specific events (Simon et al., 2000). Business experience and international experience may alter perceptions and affect the accuracy of the parameter estimates related to the perception variable. To further corroborate the presence of such bias, we carried out a Wilcoxon signed-rank test to examine whether entrepreneurs' perceptions experienced a significant change between 2007 and 2008. The result indicates that the proportion of individuals affected by the presence of a fear of business failure (Z-value: 5.769) is significantly different at the $1 \%$ level between these years. Consequently, to correct for this potential bias among the sampled entrepreneurs, the variable related to the risk perception is introduced as a lagged term.

--- Insert Table 2 about here ---

In this study, control variables refer to entrepreneurial characteristics frequently addressed in previous research, namely, gender and age (Manolova et al., 2010). As for business features, we consider firm size which is measured as the number of employees and firm age, expressed in years (Westhead et al., 2001; Majocchi et al., 2005). In addition, we have generated a set of dichotomous control variables linked to the industry sector (dummy variables to distinguish firms in manufacturing, retail and service industries) and to the geographic region.

\subsection{Method}

To correctly test the proposed hypotheses and identify the factors that affect the probability that the sampled Romanian entrepreneurs adopt different decisions related to export behaviour, we have chosen the multinomial logit regression as a methodological tool. We identified from the dataset three mutually exclusive actions linked to export behaviour (entry, sustainability and de-internationalisation). The values assigned to every type of export behaviour only reflect different categories and the ordinal value has no further meaning. The multinomial logit is estimated by the maximum likelihood method (Greene, 2003) and for the purposes of this paper it takes the form 
$\operatorname{Pr}\left(Y_{i}=k\right)=e^{\beta_{j} X_{i}} / \sum_{j=0}^{3} e^{\beta_{j} X_{i}}$, where $k(k=0,1,2,3)$ refers to the different choices under analysis namely, no export activities and the three types of decisions linked to export behaviour, respectively. The full model to be estimated follows:

Export

behaviour $_{i}=\beta_{0}+\beta_{1}$ Entrepreneur's human capital and perception $_{i}$

$+\beta_{2}$ Control variables ${ }_{i}+\varepsilon_{i}$

In the equation (1) $\beta_{0}$ is the constant term, $\beta_{j}$ refers to the vector of parameter estimates for the $j$ th independent variables and $\varepsilon_{i}$ is the logistic distributed disturbance term for the ith observation. The variables related to the entrepreneur's human capital and perception refer to the completion of management studies, the labour experience, the presence of entrepreneurial teams and the perception of a fear of business failure. The control variables correspond to the entrepreneur's gender and age, firm size and age, industry dummies (distinguishing between manufacturing, retail and service firms) and regional dummies.

\section{Results}

This section presents the results of the empirical analysis based on the equation (1). Table 3 displays the empirical findings when the dependent variable comprises the different decisions linked to exporting. We estimated different model specifications for ensuring the consistency of the parameters. The coefficients from regressions that only consider entrepreneur's attributes do not qualitatively vary with respect to the full model presented in Table 3. As an additional robustness check, we carried out the Independence of Irrelevant Alternatives test (IIA) to verify whether omitting categories in the dependent variable yields more consistent and efficient parameter estimates (Hausman and McFadden, 1984). The results of the IIA test indicate that the export entry alternative is independent from the sustainable export alternative (chi2:38.91 and $p<0.10$ ). The de-internationalisation alternative is not irrelevant and its exclusion leads to inefficient coefficients, especially in the case of the export entry choice (chi2:951.35 and $p<0.01$ ). These results confirm the presence of specific factors affecting the different export choices and consequently, validate our approach to export behaviour. 
As for the key results of the study, from Table 3 we observe that completion of management studies increases the probability to engage in exporting supporting Hypothesis 1a. However, this variable shows as not significant in the case of regular exporters. Thus, Hypothesis $1 \mathrm{~b}$ which proposes a positive relationship between the completion of management studies and export sustainability is not supported. In the case of labour experience, we observed that this coefficient is not statistically significant in relationship to export entry, failing to support Hypothesis 2a. To the contrary, the results report a strong positive relationship between labour experience and export sustainability. Therefore, Hypothesis $2 b$ is supported. Our empirical findings are in accordance with Hypothesis $3 \mathrm{a}$ as they reveal that the presence of an entrepreneurial team is a relevant factor explaining export initiation. Yet, the parameter estimate for this variable is not statistically significant in the case of the export sustainability category, providing no support to Hypothesis 3b. Finally, the variable linked to the entrepreneurial fear of business failure does not explain export entry or export sustainability, so our hypotheses $4 \mathrm{a}$ and $4 \mathrm{~b}$ are not supported. Nevertheless, it is worth noting that this factor significantly increases the probability of SMEs' deinternationalisation.

\section{Discussion}

The empirical findings in Table 3 indicate that the analysed export decisions are driven by specific factors and the observed differences in these behavioural paths require a more comprehensive analysis of the emerging profiles identified: new exporters, sustainable exporters and de-internationalisers. To provide further robustness to the analysis from a statistical point of view, this section is complemented by the results of Wald tests that examine whether the coefficients associated to the analysed variables exhibit significant differences across the different export decisions.

According to the results we observe that those entrepreneurs who decide to engage in exporting benefit from greater levels of human capital. In particular, the Wald test indicates that the completion of management studies is an important factor that explains differences between new exporters and deinternationalisers (chi2: 4.25, $p<0.05)$. As previously emphasised by studies 
undergone in the CEE markets (Fogel and Zapalska, 2001; Malo and Norus, 2009) formal business education on behalf of the entrepreneur increases the international propensity of SMEs. It is thus reasonable to argue that the completion of higher education in management studies enlarges business horizons and enhances the ability of identifying and pursuing business opportunities beyond the national border. The findings suggest the presence of a substitution effect between labour experience and entrepreneurial teams. Among new exporters, the existence of an entrepreneurial team raises the probability of entering foreign markets. The coefficient linked to this variable for new exporters is significantly higher than that obtained for sustainable exporters and de-internationalisers (chi2: $3.33, p<0.10$ and chi2: $2.85, p<0.10$, respectively).

This key finding could signal that, to overcome their relatively lower labour experience, entrepreneurs who decide to start selling overseas rely on entrepreneurial partners to benefit from a greater pool of human and social capital (Uhlenbruck et al., 2003; Loane et al., 2007).

Concerning the second group of exporting firms, sustainable exporters, the results in Table 3 demonstrate that labour experience by the entrepreneur has a significant positive effect over export sustainability. This result is corroborated by the Wald test which confirms that the positive impact of labour experience on export sustainability is significantly greater than the impact of labour experience over de-internationalisation (chi2: 12.53, $p<0.01$ ). This is consistent with the observations by Leonidou et al. (1998), Bell et al. (2004), Wheeler et al. (2008) and Evers (2011) that professional experience of the entrepreneur influences export behaviour and may ultimately lead to increased international commitment. The empirical findings also reveal that younger entrepreneurs run businesses with regular international activity. It is important to remark, considering the idiosyncrasy of the Romanian context, that the labour experience gained by the entrepreneurs in the transitional environment (average labour experience reported is of 13 years) has a powerful positive impact on their commitment and effort to sustain export activities.

Our results suggest that once a SME exports the presence of specific risks increases the perception of business failure and hampers export continuity. This finding is similar to Manolova et al. (2002) and Ruzzier et al. (2007) who report that less riskaverse entrepreneurs are more involved in exporting. Arguably over enthusiastic entrepreneurs, once eager to get involved in exporting, may be overwhelmed by the 
complexity of operations in the international arena. Ultimately, they may succumb to fear of failure and opt to exit the export markets. However, we highlight that this is not necessarily linked to business failure, as by discontinuing exporting a firm may free resources that can be later on re-invested in more profitable markets (Welch and Benito, 1996; Fletcher, 2008).

\section{Conclusions, implications and future research directions}

In this study we attempted to bridge the gap in the SMEs' internationalisation field regarding the multidimensional nature of exporting. In doing so, we propose that the presence of specific resources related to the entrepreneur may help overcome resources' shortage across SMEs and explain the adoption of the different decisions related to exporting: entry, sustainability and de-internationalisation. Hence, the significance of this research not only flows from a particular empirical design that simultaneously evaluates the different export choices, but also from the recognition that international activities by small businesses are a crucial component necessary to consolidate the market economy in the CEE countries.

This paper enriches the international business literature dealing with export determinants of SMEs in transition economies. To the best of the authors' knowledge, this is the first attempt to simultaneously examine the different export decisions, namely export initiation, sustainability and de-internationalisation, in the CEE SMEs' context. Our findings reveal that exporting is not a single event and that variables commonly used to study export propensity, linked to the entrepreneur factors, have a differential influence over the different export decisions. Export entry and sustainability are driven by the presence of entrepreneurial resources. Among the sampled entrepreneurs, engagement in export activities is a function of specific investments in entrepreneurial capital that facilitate the access to a larger market, such as managerial education and labour experience. To the contrary, de-internationalisation decisions are a consequence of a greater fear of business failure perceived by the entrepreneur.

The results of this study bring about important implications for policy makers and practitioners. The consolidation of SMEs' international activities is a policy priority in Europe (European Commission, 2011) and support policies must encourage entrepreneurial capital formation to effectively achieve this goal. We found a significant relationship between management studies and export entry. This result suggests that these policies should also target the educational system, training as well as technical 
assistance programs. A more active involvement of universities is necessary to increase the internationalisation background among entrepreneurs, as well as to enhance the skills and motivations of entrepreneurs. Training and technical assistance programs should stimulate the interaction between exporting enterprises and entrepreneurs with exporting intention in order to provide the latter with experience which can be critical for the development of more successful export-based international strategies. Furthermore, the promotion of entrepreneurial teams is another issue that should be considered by Romanian policy makers. Specific actions oriented towards the international involvement of SMEs should foster the connection between entrepreneurs as well as between individuals interested in entrepreneurial activities and support agencies. These policies could also include specific programs that require individuals to work in teams and/or organise meeting places where to make contacts and find business partners.

Although the empirical analysis focused on a sample of Romanian SMEs, the findings could be of interest to firms in other CEE countries. Nevertheless, the readers should exercise caution in attempting to generalise this study's findings to considerably different economic settings. Following Manolova et al. (2010), Zou and Ghauri (2010) and Prashantham (2011) we highlight that SMEs' internationalisation from emerging economies deserves further research attention. As future research directions it would be interesting to replicate similar studies in other emerging contexts, either within the CEE or elsewhere, so the results could be compared and ultimately generalised to larger populations. Moreover, future research should not only attempt to explore the observed differences in the impact of entrepreneurial capital on SMEs' internationalisation using longitudinal data, but should also include a greater number of factors related to entrepreneurial attributes and the organisation in order to further build on our analysis. 


\section{References}

Barney, J. (1991), "Firm resources and sustained competitive advantage', Journal of Management, Vol. 17 No. 1, pp. 99-120.

Barney, J. (2001), "Resource-based theories of competitive advantage: A ten year retrospective of the resource-based view", Journal of Management, Vol. 27 No. 6, pp. 643-650.

Bell, J., Callaghan, I., Demick, D. and Scharf, F. (2004), "Internationalisation Entrepreneurship Education”, Journal of International Entrepreneurship, Vol. 2 No. 1-2, pp. 109-124.

Benito, G.R.G. and Welch, L.S. (1997), "De-internationalisation", Management International Review, Vol. 37 No. 2, pp. 7-25.

Brown, J., Earle, J. and Lup, D. (2005), "What makes small firms grow? Finance, human capital, technical assistance, and the business environment in Romania", Economic Development and Cultural Change, Vol. 54 No. 1, pp. 33-70.

Bloodgood, J., Sapienza, H.J. and Almeida, J.G. (1996), “The internationalisation of new high-potential U.S. ventures: Antecedents and outcomes", Entrepreneurship Theory and Practice, Vol. 20 No. 4, pp. 61-76.

Castanias, R. and Helfat, S.H. (2001), "The managerial rents model: theory and empirical analysis", Journal of Management, Vol. 27 No. 6, pp. 661-678.

Cavusgil, S.T. and J. Naor (1987), "Firm and management characteristics as discriminators of export marketing activity", Journal of Business Research, Vol. 15 No. 3, pp. 221-235.

Cottarelli, C., Dell'Ariccia., G. and Vladkova-Hollar, I. (2005), "Early birds, late risers, and sleeping beauties: Bank credit growth to the private sector in Central and Eastern Europe and in the Balkans", Journal of Banking \& Finance, Vol. 29 No. 1, pp. 83-104.

Dhanaraj, C. and Beamish, P.W. (2003), "A resource-based approach to the study of export performance", Journal of Small Business Management, Vol. 41 No. 3, pp. $242-261$.

Dimitratos, P., Lioukas, S., Ibeh, K.I.N. and Wheeler, C. (2010), "Governance mechanisms of small and medium enterprise international partner management", British Journal of Management, Vol. 21 No. 3, pp. 754-771.

Ellman, M. (1994), Socialist Planning, Cambridge University Press, Cambridge. 
Evers, N. (2011), "International new ventures in "low tech" sectors: a dynamic capabilities perspective", Journal of Small Business and Enterprise Development, Vol. 18 No. 3, pp. 502-528.

European Commission (2010), "Internationalisation of European SMEs. Brussels: Entrepreneurship Unit”, [available at http://ec.europa.eu, accessed March 2012].

European Commission (2011), "Small business, big world - a new partnership to help SMEs seize global opportunities", Communication from the commission to the European Parliament, the Council, the European Economic and Social Committee and the Committees of the Regions, [available at http://eur-lex.europa.eu, accessed March 2012].

Fletcher, R. (2008), “The internationalisaition from a network perspective: A longitudinal study”, Industrial Marketing Management, Vol. 37 No. 8, pp. 953-964.

Flecher, M. and Prashantham, S. (2011), "Knowledge assimilation processes of rapidely internationalising firms: Longitudinal case studies of Scottish SMEs", Journal of Small Business and Enterprise Development, Vol. 18 No. 3, pp. 475-501.

Fogel, G. and Zapalska, A. (2001), "A comparison of small and medium-sized enterprise development in Central and Eastern Europe", Comparative Economic Studies, Vol. 43 No. 3, pp. 35-68.

Greene, W. (2003), Econometric Analysis, Fifth edition, Upper Saddler River, New Jersey.

Hausman, J. and McFadden, D. (1984), "Specification tests for the Multinomial Logit Model”, Econometrica, Vol. 52 No. 5, pp. 1219-1240.

Hitt, M. A., Bierman, L., Uhlenbruck, K. and Shimizu, K. (2006), "The importance of resources in the internationalisation of professional service firms: The good, the bad, and the ugly", Academy of Management Journal, Vol. 49 No. 6, pp. 1137-1157.

Ibeh, K.I.N. (2004), "Furthering export participation in less performing developing countries: The effects of entrepreneurial orientation and managerial capacity factors", International Journal of Social Economics, Vol. 31 No. 1/2, pp. 94-110.

Kelemen, M. (1999), "The myth of restructuring, 'competent' managers and the transition to a market economy: A Romanian tale", British Journal of Management, Vol. 10 No. 3, pp. 199-208.

Lafuente, E. and Rabetino, R. (2011), "Human capital and growth in Romanian small firms", Journal of Small Business and Enterprise Development, Vol. 18 No. 1, pp. 71-96. 
Lafuente, E., Vaillant, Y., Rialp, J. (2007), "Regional Differences in the Influence of Role Models: Comparing the Entrepreneurial Process of Rural Catalonia”, Regional Studies, Vol. 41 No. 6, pp. 779-795.

Lamb, P., Sandberg, J. and Liesch, P.W. (2011), "Small firm internationalisation unveiled through phenomenography", Journal of International Business Studies, Vol. 42 No. 5, pp. 672-693.

Leonidou, L. C., Katsikeas, C.S. and Piercy, N.F. (1998), "Identifying managerial influences on exporting: Past research and future directions", Journal of International Marketing, Vol. 6 No. 2, pp. 74-102.

Liesch, P.W., Welch, L.S. and Buckley, P.J. (2011), "Risk and uncertainty in internationalisation and international entrepreneurship studies: Review and conceptual development", Management International Review, Vol. 51 No. 6, pp. 851-873.

Loane, S. and Bell, J. (2006), "Rapid internationalisation among entrepreneurial firms in Australia, Canada, Ireland and New Zealand: An extension of the network approach", International Marketing Review, Vol. 23 No. 5, pp. 467-485.

Loane, S., Bell, J. and McNaughton, R. (2007), “A cross-national study of the impact of management teams on the rapid internationalisation of small firms", Journal of World Business, Vol. 42 No. 4, pp. 489-504.

Luthans, F., Stajkovic, A.D. and Ibrayeva, E. (2000), "Environmental and psychological challenges facing entrepreneurial development in transitional economies", Journal of World Business, Vol. 35 No. 1, pp. 95-110.

Majocchi, A., Bacchiocchi, E. and Mayrhofer, U. (2005), "Firm size, business experience and export intensity in SMEs: A longitudinal approach to complex relationships", International Business Review, Vol. 14 No. 6, pp. 719-738.

Malo, S. and J. Norus (2009), "Growth dynamics of dedicated biotechnology firms in transition economies. Evidence from the Baltic countries and Poland", Entrepreneurship and Regional Development, Vol. 21 No. 5/6, pp. 481-502.

Manolova, T.S., Brush, C.G., Edelman, L.F. and Greene, P.G. (2002), "Internationalisation of small firms. Personal factors revisited", International Small Business Journal, Vol. 20 No. 1, pp. 9-31.

Manolova, T.S., Manev, I.M. and Gyoshev, B.S. (2010), "In good company: The role of personal and inter-firm networks for new-venture internationalisation in a transition economy", Journal of World Business, Vol. 45 No. 3, pp. 257-265. 
Meyer, K. E. and Peng, M. W. (2005),"Probing theoretically into central and eastern Europe: transitions, resources, and institutions", Journal of International Business Studies, Vol. 36 No. 6, pp. 600-621

Meyer, K.E. and Gelbuda, M. (2006), "Process perspectives in international business research in CEE”, Management International Review, Vol. 46 No. 2, pp. 143-164.

Miocevic, D. and Crnjak-Karanovic, B. (2011), "Cognitive and information-based capabilities in the internationalisation of small and medium-sized enterprises: The case of Croatian exporters", Journal of Small Business Management, Vol. 49 No. 4, pp. 537-557.

Morgan, N. A., Katskieas, C.S. and Vrohies, D.W. (2012), "Export marketing strategy implementation, export marketing capabilities, and export venture performance", Journal of Academy Marketing Science, Vol. 40 No. 2, pp. 271-289.

Nielsen, S. (2010), “Top management team internationalisation and firm performance: The mediating role of foreign market entry", Management International Review, Vol. 50 No. 2, pp. 185-206.

North, D.C. (1990), Institutions, institutional change and economic performance. New York: Cambridge University Press.

North, D.C. (2005), Understanding the Process of Economic Change. Princeton University Press, Princeton, NJ.

Peng, M.W. (2001), "The resource-based view and international business", Journal of Management, Vol. 27 No. 6, pp. 803-829.

Penrose, E. (1959), The Theory of the Growth of the Firm, John Wiley, New York.

Pissarides, F. (1999).“Is lack of funds the main obstacle to growth? Ebrd's experience with small- and medium-sized businesses in Central and Eastern Europe", Journal of Business Venturing, Vol. 14 No. 5-6, pp. 519-539.

Prashantham, S. (2011), "Social Capital and Indian Micromultinationals", British Journal of Management, Vol. 22 No. 1, pp. 4-20

Reuber, A.R. and Fisher, E. (2002), "Foreign sales and small firm growth: The moderating role of the management team", Entrepreneurship Theory and Practice, Vol. 27 No. 1, pp. 29-45.

Ruzzier, M., Antoncic, B., Hisrich, R.D. and Konecnik, M. (2007), "Human capital and SME internationalisation: A structural equation modelling study", Canadian Journal of Administrative Science, Vol. 24 No. 1, pp. 15-29. 
Simon, M., Houghton, S. and Aquino, K. (2000), “Cognitive biases, risk perception, and venture formation: How individuals decide to start companies", Journal of Business Venturing, Vol. 15 No. 2, pp. 113-134.

Smallbone, D. and Rogut, A. (2005), “The challenge facing SMEs in the EU's new member states", International Entrepreneurship and Management Journal, Vol. 1 No. 2, pp. 19-240.

Smallbone, D., Piasecki, B., Venesaar, U., Todovro, K. and Labrianidis, L. (1998), "Internationalisation and SME development in transition economies: an international comparison", Journal of Small Business and Enterprise Development, Vol. 5 No. 4, pp. 363-375.

Sousa, C.M.P., Martínez-López, F.J. and Coelho, F. (2008), "The determinants of export performance: A review of the research in the literature between 1998 and 2005”, International Journal of Management Reviews, Vol. 10 No. 4, pp. 343-374.

Stephen F., Urbano D. and van Hemmen, S. (2009), "The responsiveness of entrepreneurs to working time regulations", Small Business Economics, Vol. 32 No. 3, pp. 259-276.

Tolstoy, D. and Agndal, D. (2010), "Network resources combinations in the international venturing of small biotech firms", Technovation, Vol. 30 No. 1, pp. 2436.

Uhlenbruck, K., Meyer, K.E. and Hitt, M.A. (2003), "Organisational transformation in transition economies: Resource-based and organisational learning perspectives", Journal of Management Studies, Vol. 40 No. 2, pp. 257-282.

Vaillant, Y., Lafuente, E. (2007), "Do different institutional frameworks condition the influence of local fear of failure and entrepreneurial examples over entrepreneurial activity?", Entrepreneurship and Regional Development, Vol. 19, pp. 313-337.

Welch, L.S. and Benito, G.R.G. (1996), "De-internationalisation", Paper presented at the Annual Meeting of the Academy of International Business. Banff, Canada, September, 26-29.

Westhead, P., Wright, M. and Ucbasaran, D. (2001), "The internationalisation of new and small firms: A resource-based view", Journal of Business Venturing, Vol. 16 No. 4, pp. 333-358.

Wheeler, C., Ibeh, K. and Dimitratos, P. (2008), "UK export performance research: Review and implications”, International Small Business Journal, Vol. 26 No. 2, pp. 207-239. 
Yamakawa, Y., Peng, M. W. and Deeds, D.L. (2008), "What drives new ventures to internationalise from emerging to developed economies?", Entrepreneurship Theory and Practice, Vol. 32 No. 1, pp. 59-82.

Zou, H. and Ghauri, P.N. (2010), "Internationalising by learning: The case of Chinese high-tech new ventures", International Marketing Review, Vol. 27 No. 2, pp. 223244. 


\section{List of Tables}

Table 1. Geographic distribution of the sampled firms

\begin{tabular}{lcc}
\hline Region & Number of firms & Proportion (\%) \\
\hline Bucharest & 57 & $17.87 \%$ \\
Centre & 34 & $10.66 \%$ \\
West & 28 & $8.78 \%$ \\
North West & 28 & $8.78 \%$ \\
North East & 21 & $6.58 \%$ \\
South & 43 & $13.48 \%$ \\
South West & 53 & $16.61 \%$ \\
South East & 55 & $17.24 \%$ \\
\hline Total & $\mathbf{3 1 9}$ & $\mathbf{1 0 0 . 0 0 \%}$ \\
\hline
\end{tabular}

The regional distribution follows the NUTS criteria (EUROSTAT, 1999).

Table 2. Descriptive statistics for the selected independent variables

\begin{tabular}{lccc}
\hline & Exporter in 2008 & Non-exporter & Overall \\
\hline $\begin{array}{l}\text { Entrepreneur's human capital } \\
\text { and perception }\end{array}$ & & & \\
Management studies & 0.6909 & 0.5795 & 0.5987 \\
& $(0.4664)$ & $(0.4946)$ & $(0.4909)$ \\
Labour experience (years) & $12.9636 * *$ & 10.3977 & 10.8401 \\
Number of founders & $(7.7578)$ & $(7.6852)$ & $(7.7465)$ \\
(Entrepreneurial team) & 1.5818 & 1.5076 & 1.5204 \\
Fear of business failure & $(0.7121)$ & $(0.6754)$ & $(0.6813)$ \\
& 0.2182 & 0.1591 & 0.1693 \\
& $(0.4168)$ & $(0.3665)$ & $(0.3756)$
\end{tabular}

\section{Control variables}

\begin{tabular}{lccc} 
& 0.7273 & 0.6667 & 0.6671 \\
Entrepreneur's gender (1 for male) & $(0.4495)$ & $(0.4723)$ & $(0.4683)$ \\
Entrepreneur's age (years) & 39.2182 & 39.0871 & 39.1097 \\
& $(10.0253)$ & $(8.2662)$ & $(8.5780)$ \\
Firm age (years) & $7.0909 * *$ & 6.1136 & 6.2821 \\
& $(5.0269)$ & $(5.1769)$ & $(5.1569)$ \\
Firm size (number of employees) & 5.5636 & 5.5189 & 5.5266 \\
& $(7.5835)$ & $(6.9056)$ & $(7.0147)$ \\
Manufacturing & 0.0364 & 0.0341 & 0.0345 \\
& $(0.1889)$ & $(0.1818)$ & $(0.1828)$ \\
Retail & 0.3818 & 0.3295 & 0.3385 \\
& $(0.4903)$ & $(0.4709)$ & $(0.4740)$ \\
Services & 0.5818 & 0.6364 & 0.6270 \\
& $(0.4978)$ & $(0.4820)$ & $(0.4844)$ \\
\hline Number of observations & 55 & 264 & 319 \\
Standard deviation is presented in brackets. $* * *, * * *$ indicate & significance at the $10 \%, 5 \%$ and $1 \%$, \\
respectively (Kruskal-Wallis test). & & &
\end{tabular}


Table 3. Multinomial Logit: Factors affecting transitions in-and-out of exporting

\begin{tabular}{|c|c|c|c|}
\hline & New exporter & Regular exporter & $\begin{array}{c}\text { De- } \\
\text { internationalisation }\end{array}$ \\
\hline \multicolumn{4}{|l|}{$\begin{array}{l}\text { Entrepreneur's human capital and } \\
\text { perception }\end{array}$} \\
\hline Management studies & $2.730(1.602)^{*}$ & $0.296(0.342)$ & $-1.595(1.553)$ \\
\hline Labour experience (ln years) & $0.512(0.347)$ & $0.800(0.269) * * *$ & $0.172(0.401)$ \\
\hline $\begin{array}{l}\text { Number of founders (Entrepreneurial } \\
\text { team) }\end{array}$ & $0.839(0.490)^{*}$ & $0.072(0.269)$ & $-1.043(1.322)$ \\
\hline Fear of business failure & $-0.628(1.001)$ & $0.433(0.390)$ & $2.575(1.473)^{*}$ \\
\hline \multicolumn{4}{|l|}{ Control variables } \\
\hline Gender of the entrepreneur ( 1 for male) & $1.179(0.921)$ & $0.301(0.396)$ & $-0.886(0.841)$ \\
\hline Entrepreneur's age (ln years) & $0.792(1.886)$ & $-1.823(0.932) * *$ & $0.221(3.067)$ \\
\hline Firm size (ln number of employees) & $0.408(0.405)$ & $-0.242(0.186)$ & $1.004(0.298)^{* * *}$ \\
\hline Industry dummies & Yes & Yes & Yes \\
\hline Intercept & $-12.426(6.664)^{*}$ & $2.683(3.202)$ & $-5.301(13.416)$ \\
\hline \multicolumn{4}{|l|}{ Regression statistics } \\
\hline Pseudo R2 & 0.1144 & & \\
\hline LR (chi2) & $3763.20 * * *$ & & \\
\hline Log likelihood & -174.9076 & & \\
\hline Number of observations & 319 & & \\
\hline
\end{tabular}

